\title{
Effect of Students' Self-Directed Learning to Self-Care in Organs of Human Body Lesson on Daily Life
}

\author{
Reni Marlina ${ }^{1 凶}$, Dian Miranda $^{2}$, Marmawi $^{3}$, Andri Maulidi ${ }^{4}$ \\ ${ }^{1}$ Pendidikan Biologi, Universitas Tanjungpura \\ ${ }^{2,3}$ Pendidikan Guru Pendidikan Anak Usia Dini, Universitas Tanjungpura \\ ${ }^{4}$ Biologi, Universitas Palangka Raya
}

\begin{abstract}
This study aims to describe the effects of self-directed learning skills on self-care for organs of the body among five-year-old children in the kindergartens of Kubu Raya District, West Kalimantan. The methods used in this study were qualitative and quantitative research methods. The results of this study showed that the respondents were able to diagnose learning needs with good criteria, had not been able to formulate learning objectives independently, were able to identify learning resources with good criteria, were able to choose and apply appropriate learning strategies, and were happy to evaluate their learning outcomes with the very good criteria. In the aspect of self-care for organs, the students had knowledge about the organs and understood how to maintain with good criteria. The students had used their time to care for organs, had not been able to describe the functions of organs, and were able to analyze knowledge about personal health with very good criteria. The results of the analysis indicates that self-directed learning affected self-care for organs of the body. It is recommended for teachers and parents to teach the human body recognition not only having an accessory but more emphasis on practice in daily life.
\end{abstract}

Keywords: self-directed learning; body organ.

\section{Abstrak}

Penelitian ini bertujuan untuk mendeskripsikan pengaruh kemampuan belajar mandiri dengan kemandirian merawat organ tubuh anak usia 5 tahun di TK sekabupaten Kubu Raya, Kalimantan Barat. Metode yang digunakan dalam penelitian ini adalah penelitian kualitatif dan kuantitatif. Hasil penelitian ini menunjukkan bahwa responden telah mampu mendiagnosis kebutuhan belajar dengan kriteria baik, responden belum mampu merumuskan tujuan pembelajaran secara mandiri, responden telah mampu mengidentifikasi sumber belajarnya dengan kriteria baik, telah mampu memilih dan menerapkan strategi pembelajaran yang sesuai, dan senang mengevaluasi hasil belajar mereka dengan kriteria sangat baik. Pada aspek kemandirian dalam merawat organ tubuh diperoleh hasil bahwa siswa telah mengenal organ tubuh dan memahami cara menjaga dan merawat organ tubuh dengan kriteria baik, siswa belum mampu memaparkan fungsi dan manfaat organ tubuh, siswa telah menggunakan waktu dengan baik dalam merawat organ tubuh, dan telah mampu menganalisis pengetahuan tentang kesehatan diri dengan kriteria sangat baik. Mengacu pada hasil analisis yang diperoleh, mengindikasikan bahwa kemandirian belajar berpengaruh pada kemandirian merawat organ tubuh. Direkomendasikan kepada para guru dan orang tua untuk mengenalkan organ tubuh tidak hanya berupa teori namun lebih ditekankan pada implementasinya dalam kehidupan sehari-hari.

Kata Kunci: kemandirian belajar; organ tubuh

Copyright (c) 2019 Reni Marlina, Dian Miranda, Marmawi, Andri Maulidi

$\triangle$ Corresponding author :

Address : Pontianak, Indonesia

Email : renitahak@yahoo.com

ISSN 2356-1327 (Media Cetak)

ISSN 2549-8959 (Media Online) 


\section{INTRODUCTION}

Learning is the process of gaining knowledge, skills, and values that will be retained by individuals to determine their identity in society. Through learning, a person can improve knowledge and skills to solve various problems they face. Through learning, humans can make achievement, change, succeed, and even find inner peace in life. A person's ability in learning will determine the quality of their life. Therefore learning abilities must be developed from an early age. A person who truly learns will be seen in their personality change in the form of improvement of the quality of behavior, such as improving knowledge, skills, thinking, understanding, attitudes, and various other abilities. In this era of industrial revolution 4.0, information sources are wide open and easily accessible to everyone to learn. Even children at a very early age can also take advantage of these changes. Therefore in this era every child is expected to develop optimally, so they must be able to take advantage of the technological advances to improve their quality. To be able to take advantage of these technologies a person must have independence in learning. They should not be dependent on other people or educators all the time, or wait for new instruction to continue the learning process, or depend on learning resources provided by other people or educators. Children must have the initiative to find their own learning resources. Levettjones(2005) argued that self-directed learning is not only needed in the world of education, but also in the world of employment. Furthermore he stated that self-directed learning has become a prerequisite for living in the present world with its rapid dynamics of change.

Loyens et al., (2008)wrote that selfdirected learning is a person's ability to take initiative and be responsible in setting the learning goals, identifying and describing learning difficulties, identifying learning resources, choosing, and implementing learning strategies, and evaluating their own learning outcomes. Tahar \& Enceng(2006)also revealed that self-directed learning has three fundamental indicators, namely self-initiative with or without the help of others in learning, being responsible for achieving learning goals, and having high motivation in managing learning resources. Referring to the definitions, it can be concluded that self-directed learning is the ability to control oneself and one's responsibility in learning. This self-directed learning ability requires someone to make a decision about what will be learned, what methods and materials are used for learning, and determine steps to measure the success of their learning. It also needs to be understood that the self-directed learning does not mean that students must learn on their own. Selfdirected learning is the nature, attitude, and ability of students to carry out learning activities alone or with the help of others. Learning activities are carried out based on their own desire to master certain competencies so they can solve problems encountered.

Many things affect the self-directed learning, such as motivation to learn, selfconfidence, conscience, experience, and intelligence(Cazan \& Schiopca, 2014), where the combination of all is called readiness in self-directed learning. This has been proven by Ramli at. al, (2018)in their research on the fourth year students of the medical school at Tadulako University, where they found that both family environment and academic environment had a significant positive influence on internal factors in the form of achievement motivation, interest in learning and self concept about academics. Their research also found that internal factors have an important role in the readiness of selfdirected learning and have been proven to play a role as mediators of the relevance of external factors with readiness for self-directed learning. Based on this study, it was found that external and internal factors proved to be influential on students' self-directed learning readiness.Knowles in Saeid \& Eslaminejad (2016) revealed that self-directed learning is the ability of someone to take the initiative, with or without the help of others, in diagnosing their learning needs, formulating learning goals, identifying learning resources that come from humans and material for learning, choosing and applying appropriate 
learning strategies, and evaluating learning outcomes. Learning strategies and learning outcomes that are appropriate to be measured in this study are biology science material especially on how to care for organs of the body.

One of the ways to master and introduce biology science to early childhood students is by introducing organs and how to care for them. This is important because based on Sutama (2001) research, students tend to study biology by storing it without any implementation, so that it cannot be applied in real life. Thus, independence is needed to apply the knowledge that has been learned in schools, not only in the learning process but also in the process of caring for the organs that have been studied. According to Miarso (2005) one of the advantages of teaching students to be able to live independently both in the learning process and in caring for organs is that students will be more advanced and more creative.

Previous study Long (1991) have shown that self-directed learning is a strong factor for influencing students learning themselves. Similar with this study indicate that the selfdirected learning in human body recognition is one of the students way to learn independently.

\section{METHODOLOGY}

The methods used in this research were qualitative and quantitative research methods. Qualitative research was carried out in the form of a survey conducted on 5-year-old children from 19 kindergartens in Kubu Raya District, West Kalimantan, Indonesia. The survey was conducted by asking the contents of the questionnaire directly to the children and parents. Samples in this study were students five year old in kindergarten at Kubu Raya regency. This study aims to describe the ability of self-directed learning in children aged five years and measure its effect on independence in caring for their organs. The variables used by the researchers are $\mathrm{X}$ and $\mathrm{Y} . \mathrm{X}$ is selfdirected learning and $\mathrm{Y}$ is self-care for organs of the body. The tests given include test instruments (Winkel, 2004), classic assumption tests (Sudijono, 2011), multiple regression analysis, and hypothesis testing (Sanjaya, 2006).

The instrument used in this research was questionnaire compiled theory where he wrote learning competencies include diagnosing learning needs, formulating learning objectives, identifying learning resources, choosing and applying appropriate learning strategies, and evaluating learning outcomes. Another instrument used was related to self-care for organs of the body such as introduction of organs of the body, describing the functions of organs of the body, understanding how to maintain and care for organs of the body, time provided in caring for organs of the body, and analyzing knowledge about personal health. The instruments compiled based on the above indicators were asked directly to the respondents in the Likert scale form with three answer options, namely strongly agree (SA), Agree (A), and strongly disagree (SD); and to ensure the validity of the data provided by the respondents given the age of the respondent which is still too young, the researchers clarified the data to the parents of the respondents through the questionnaire shared by the researchers and filled out in writing by the respondents' parents. The collected research data were analyzed with descriptive quantitative methods, namely classifying the data based on the number of respondents who agreed or disagreed with what was stated in the questionnaire in accordance with indicators of self-directed learning. 


\section{RESULTS AND DISCUSSION}

The results of the study on self-directed learning are shown in the following data.

Table 1. Results of Measurement of Student Self-directed learning

\begin{tabular}{|c|c|c|c|c|c|c|}
\hline \multirow[t]{2}{*}{ Indicator } & \multicolumn{3}{|c|}{$\begin{array}{c}\text { Number of } \\
\text { Respondents } \\
\end{array}$} & \multicolumn{3}{|c|}{ Percentage } \\
\hline & $\mathbf{S A}$ & $\mathbf{A}$ & SD & $\mathbf{S A}$ & $\mathbf{A}$ & SD \\
\hline $\begin{array}{l}\text { Diagnosing } \\
\text { learning needs }\end{array}$ & 153 & 7 & 56 & 71 & 3 & 26 \\
\hline $\begin{array}{l}\text { Formulating } \\
\text { learning } \\
\text { objectives }\end{array}$ & 0 & 0 & 216 & 0 & 0 & $\begin{array}{c}10 \\
0\end{array}$ \\
\hline $\begin{array}{l}\text { Identifying } \\
\text { learning } \\
\text { resources }\end{array}$ & 135 & 21 & 60 & 62 & $\begin{array}{l}1 \\
0\end{array}$ & 28 \\
\hline choosing and & 192 & 7 & 17 & 89 & 3 & 8 \\
\hline $\begin{array}{l}\text { applying } \\
\text { appropriate } \\
\text { learning } \\
\text { strategies }\end{array}$ & 188 & 18 & 10 & 87 & 8 & 5 \\
\hline $\begin{array}{l}\text { evaluating } \\
\text { learning } \\
\text { outcomes }\end{array}$ & 209 & 7 & 0 & 97 & 3 & 0 \\
\hline
\end{tabular}

* $\quad \mathrm{SA}=$ Strongly Agree

$$
\begin{aligned}
& \mathrm{A}=\text { Agree } \\
& \mathrm{SD}=\text { Strongly Disagree }
\end{aligned}
$$

From the data above, it can be explained that self-directed learning in 5-year-old children in kindergartens in Kubu Raya District is as follows: $74 \%$ of the children could diagnose their learning needs, they said they could determine what they want and would learn according to their needs, but even so $100 \%$ of the children and parents agreed that children still need parental guidance in determining their learning objectives.In terms of the ability to identify learning resources, $73 \%$ of the children were able to do it by asking for guidance from their parents and looking for other sources of reference in the form of their reading books. This is in line with what (Deporter \& Mike, 2008) stated that selfdirected learning is the result of uptake in the formation of family lifestyles that give freedom to children to search and find learning resources according to their interests.

As many as $89 \%$ of children strongly agreed and 3\% agreed if they can choose and apply appropriate learning strategies, i.e. they study before entering school, or study after entering school. It means that $92 \%$ of the respondents were able to apply one aspect of self-directed learning, namely choosing and applying strategies that are appropriate to themselves. As many as $100 \%$ of the children were able to evaluate their learning outcomes, which can be seen when they said they were happy to do the prepared worksheet. Figure 1 below illustrates the correlation between students' and parents' opinions about selfdirected learning.

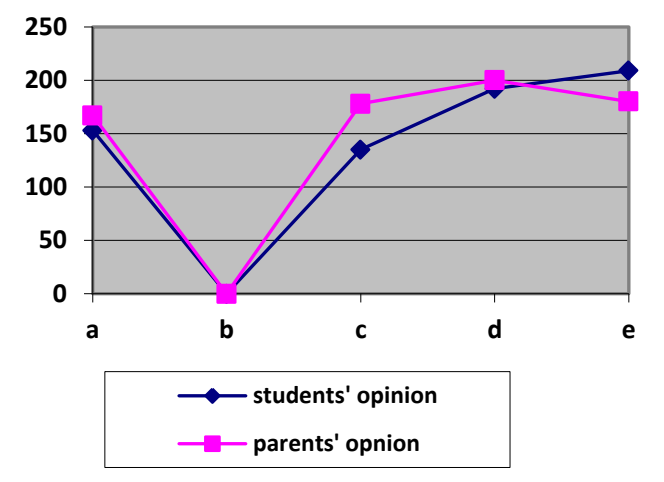

Figure 1. Correlation between of Students' and Parents' Opinionson Self-directed learning Legend:
a : diagnosing learning needs
b : formulating learning objectives
c : identifying learning resources
d : choosing and applying appropriate learning strategies
e $\quad$ : evaluating learning outcomes

The results of the study on self-care for organs of the body are shown in the following data (Table 2).

Table 2. Results of assessment of self-care for organs of the body

\begin{tabular}{lcccccc}
\hline \multicolumn{1}{c}{ Indicator } & \multicolumn{3}{c}{$\begin{array}{c}\text { Respondents } \\
\text { Percentage }\end{array}$} \\
\cline { 2 - 7 } & SA & A & SD & SA & A & SD \\
\hline $\begin{array}{l}\text { Introduction of } \\
\text { organs of the body }\end{array}$ & 160 & 0 & 56 & 74 & 0 & 26 \\
\hline $\begin{array}{l}\text { Describi the } \\
\text { functions of organs } \\
\text { of the body }\end{array}$ & 0 & 16 & 200 & 0 & 8 & 92 \\
\hline $\begin{array}{l}\text { Understandinf how } \\
\text { to maintain and } \\
\text { care for organs of } \\
\text { the body }\end{array}$ & 156 & 0 & 60 & 72 & 0 & 28 \\
\hline $\begin{array}{l}\text { Time provided in } \\
\text { caring for organs } \\
\text { of the body }\end{array}$ & 199 & 0 & 17 & 92 & 0 & 8 \\
\cline { 2 - 7 } & 108 & 98 & 10 & 50 & 45 & 5 \\
\hline $\begin{array}{l}\text { Introduction of } \\
\text { organs of the body }\end{array}$ & 200 & 16 & 0 & 93 & 7 & 0 \\
\hline
\end{tabular}

* $\quad \mathrm{SA}=$ Strongly Agree

$\mathrm{A}=$ Agree

$\mathrm{SD}=$ Strongly Disagree 
Self-care for organs of the body unknown to the students is related to the function of each organ of the body. This indicates that self-care for organs of the body among the students is not really good as indicated by the unknown functions of organs such as the functions of the nails and the nose. However, this aspect did not have a significant effect on the final results of students' self-care for organs of the body and did not serve as a determinant of students' selfcare. This is in accordance with the opinion of Sunarsih (2009) which stated that the results of learning about the introduction of organs of the body, especially in describing the functions of the organs, are not the only factors that indicate students being independent or not independent. Figure 2 below illustrates the correlation between the students' and the parents' opinions about self-care for organs of the body.

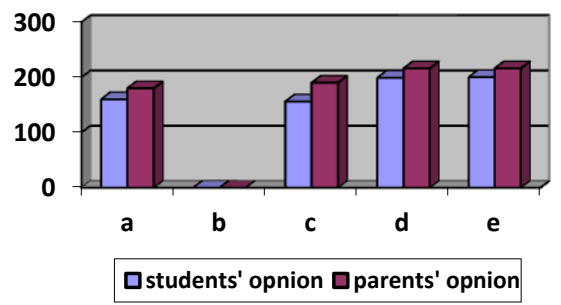

Figure 2. Correlation between of Students' and Parents' Opinions on self-care for organs of the body

\section{Legend:}

b : Describing the functions of organs of the body

c : Understanding how to maintain and care for organs of the body

d : Time provided in caring for organs of the body

e $\quad$ : Introduction of organs of the body

Based on the test given for the first time with the normality test beingconducted using the Kolmogorov-Smirnov test. The results shown in the classic assumption test include the multicollinearity test. In the multicollinearity test, it was identified that the VIF values obtained in the Coefficients table for the two variables were 2.768 and 0.361 for tolerance values. Based on these results, it can be concluded that multicollinear disorder was not experienced by the regression model. The results of calculations indicate that the constant value (a) is 2.162 , the regression value coefficient on the variable about self-directed learning $(\mathrm{X})$ is 0.338 and the coefficient on the variable of self-care for organs is 0.525 . If the regression equation is drawn from the data, thenit is $2.162+0.338(\mathrm{X})+0.525(\mathrm{Y})+\mathrm{e}$. Referring to the equation, it is known that if there is an increase in each self-directed learning, then there will also be increased selfcare for organs by 3.701 with a significance value of $p=0.002$.

In the calculation of the t-test, the value of $t$-calc is 3.331 with a significance value of $p$ $=0.001<0.05$. In addition, in the Table, it is also known that self-care for organs of the body obtains a value of $0.002<0.05$. With these data, it is clearly known that self-directed learning has an effect on self-care for organs of the body. Figure 3 illustrate the correlation between and effects of self-directed learning and self-care for organs obtained from the opinions of the parents and the students.

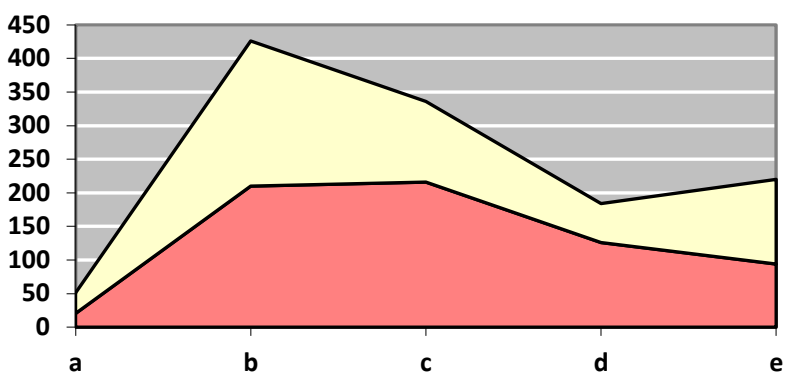

$\square$ self-directed learning and self-care for organs from parents $\square$ self-directed learning and self-care for organs from students

Figure 3. Correlationbetweenthe parents'and the students' opinions on self-directed learning and self-care for organs

\section{Legend:}

$\begin{array}{ll}\mathrm{a} & : \text { Allocation of time with family } \\ \mathrm{b} & \text { : Courage to express opinions } \\ \mathrm{c} & \text { : Participation in maintaining the } \\ & \text { cleanliness of the house } \\ \mathrm{d} & : \text { Maintenance of personal items } \\ \mathrm{e} & \text { : Decision on which equipment is good in } \\ & \text { caring for the body }\end{array}$

\section{DISCUSSION}

Basically every child is born happy to learn new things. The process of learning new things is an important part of the learning process. Children will instinctively ask questions, mimic, try new things that are of 
interest to them that they have yet to know or understand. Then it can be naturally said that children are independent learners, but when the learning process takes place, children get some obstacles that make them finally get the label "lazy to learn". Self-directed learning is an active learning activity driven by the intention or motive to master a competency to overcome a problem, and is built up with the knowledge or competence that a learner has obtained. Determination of competencies as learning objectives, and ways of achieving them, be it the determination of study time, the place of learning, the rhythm of learning, the tempo of learning, how to learn, and the evaluation of learning outcomes are self-directed. In this study, children's self-directed learning is measured through several indicators such as the ability to choose and apply appropriate learning strategies. The results of the study show that young children are able to diagnose their learning needs, determine what they want and what they will learn, and only a small number of them who still need help from parents or the teacher. Awareness of the existence of learning needs is influenced by high curiosity that raises the interest or motivation of children in learning something. Motivation or interest in learning is also affected by many aspects, such as factors in the form of physical and psychological conditions (attention, observation, response, fantasy, memory, thought, talent, and motives), while external factors include family environment, school, and society.

Children who are physically and mentally healthy will have good curiosity, allowing them to concentrate on digging for information that they consider important to satisfy their curiosity. Parents' responses in facilitating children's learning needs are among others: how parents raise them, a quiet, comfortable and conducive home environment for learning which determines their interest in learning. In addition, the school environment and the community such as teacher's teaching methods, curriculum, facilities and infrastructure, the availability of learning resources in schools, friends, neighborhood, and activities in the community also affect children's interest in learning. If the school provides a learning atmosphere that is in accordance with the children's characteristics such as providing interesting learning methods and providing material that is interesting and relevant to their life, it will foster their curiosity to find out more and of course they will naturally be interested in learning. With the growth of interest in learning, children will be able to diagnose their learning needs with curiosity that is created in the learning process.Selfdirected learning is also characterized by the ability to formulate learning objectives. Learning objectives are a measure of the success of learning or a behavior or appearance that will be achieved after learning. Formulating learning objectives is an important component in the learning process because it has benefits such as understanding the purpose of the learning process, facilitating the selection of teaching materials and learning resources, facilitating the selection of media and methods / learning activities, and facilitating learners to evaluate success in learning.

Formulating learning goals is an ability that must be possessed by self-directed learners. Since 1950 B.F. Skinner has suggested the importance of formulating learning goals before conducting learning activities, and it was reinforced by Robert Mager in 1962 through his book entitled Preparing Instruction Objectives. Researchers now agree that learning objectives cover three domains, as stated by Bloom, namely (1) cognitive domains that include knowledge, comprehension, application, analysis, synthesis, and evaluation; (2) affective domains that include feelings, interests, attitudes, obedience to morals, etc; (3) psycho motoric domains that include set, imitation, habituation, adaptation and origination, which are all related to aspects of skills. In this study, even though the children were able to identify their learning needs but it seems they were still unable to formulate learning objectives and determine what must be achieved in the learning process. It shows that five-year-old children are still in the stage of pre-operational development. They make decisions merely 
based on intuition, not on their rational analysis. When they know what they are going to learn, they go with the learning process based on their intuition rather than on what they have to get from the learning process; they act only on the basis of curiosity that must be satisfied. To maximize this learning process, children need other people, in this case parents or teachers, to help them determine the learning objectives they must achieve.

Another skill that must be acquired as a self-directed learner is being able to identify learning resources. Learning resources are all the things that can be used to facilitate one's learning in the form of messages, human beings, equipment, techniques/methods, environment/settings. The ability to identify learning resources that will be used is important in learning activities, because learning resources function to provide a more concrete and direct learning experience, overcome the limitations of space, time and sense capacity, enrich insight and experience to children, provide accurate and up-to-date information, increase children's learning motivation, develop children's thinking skills more critically and positively. This ability will affect the success of learning which is evident in the research conducted byNugraha at. al., (2018)on 40 students of the seventh grade of Islamic Junior High School. Their research proved that there is a significant influence of learning resources on learning achievement, where learning achievement is an indication of learning success. In this study it was found that most 5-year-olds in the kindergarten of Kubu Raya District were able to identify learning resources such as asking for direction from parents and teachers, using available books. From here it is known that children were able to take advantage of learning resources to satisfy their curiosity or to help with their learning process. The independence of children in learning is something that needs to be acquired because it teaches them to be responsible in carrying out their activities as students. Furthermore Ahmadi, (2008) stated that self-directed learning can prepare children to be individuals with initiative and actively involved in improving learning achievement.
The next skill that must be acquired is being able to choose and apply the appropriate learning strategies. Learning strategies are all components of learning material and procedures or stages of learning activities used in order to achieve certain learning objectives The choice of learning strategies should consider several factors, namely the characteristics of the learning objectives, the characteristics of the children and the way of learning, the place where learning activities take place, the learning themes, and the pattern of activities.Kostelnik et al., (1999)suggested seven types of specific learning strategies that can be used as a basis for planning and implementing learning activities in early childhood education. The types of specific learning strategies are: 1) explanatory activities, 2) guided discovery, 3) problem solving, 4) discussion, 5) cooperative learning, 6) demonstration, 7) direct instruction. Of the various types of strategies above, the learning strategies in early childhood should always prioritize aspects of play activities, singing (being joyful), and work in the sense of doing activities. Therefore, even though children engage in playing, having fun, as long as there is a process of adding new knowledge / skills in the activity, at that time they are in the process of learning.In addition to studying in class or at school, the children who were respondents in this study also said that they had studied before and after returning home from school. It was also confirmed by the stament from the parents that children often talked about what they had done during, before, and after school. They even repeat the activities.

Finally, another ability a self-directed learner must have is the ability to evaluate learning outcomes. Evaluation is very important to determine whether or not the learning has been successful. According to Linn et al., (1995) evaluation is a systematic process for collecting, analyzing and interpreting information to determine the extent to which children can achieve learning objectives. For children, evaluation is used to measure the achievement of success in learning. Children who can evaluate their learning will be more successful in learning 
because by knowing the results of their learning they will know what they have to do next wwith regard to the learning process. In this study, the children were happy when asked to work on the worksheets, because the worksheets provided to them were in accordance with their characteristics and interests. Working on the worksheets is a form of evaluation of learning outcomes. The results of the analysis showed a significance of $\mathrm{p}=$ $0.001<0.05$ which indicates that self-directed learning affected self-care for organs of the body. These results are correlated with the results of the study by Prayitno dan Erman (2004) which found that children's selfdirected learning affected independence in all aspects of daily children's lives. In addition, according to (Suhendri, 2012) school-age children have been independent in learning without the need to get orders from parents, friends, or teachers. It is also supported by Hurlock (2000) who argued that in child development science, if they are at least 5 years old, they have been able to learn something consciously.

\section{CONCLUSION}

This research has shown that 5-year-old children in kindergartens in Kubu Raya the District have demonstrated self-directed learning skills such as being able to diagnose learning needs, choosing and applying appropriate learning strategies, identifying learning resources, diagnosing learning needs, and evaluating learning outcomes, but have not been able to formulate learning objectives. To formulate learning objectives, children still need help from parents and teachers. However, teachers and parents still need to help children to improve their self-directed learning. The results of this study showed that $74 \%$ of the respondents were able to diagnose learning needs, $100 \%$ had not been able to formulate learning objectives independently, $72 \%$ were able to identify learning resources, $92 \%$ were able to choose and apply appropriate learning strategies, and $100 \%$ were happy to evaluate their learning outcomes. In the aspect of selfcare for organs of the body, the results showed that $74 \%$ of the students had knowledge about organs of the body, $92 \%$ had not been able to describe the functions of organs of the body, $72 \%$ understood how to maintain and care for organs of the body, $92 \%$ had used their time to care for organs of the body, and $100 \%$ were able to analyze knowledge about personal health. The results of the analysis showed a significance of $\mathrm{p}=0.001<0.05$ which indicates that self-directed learning affected self-care for organs of the body. It is recommended for teachers and parents to teach the human body recognition not only having an accessory but more emphasis on practice in daily life.

\section{ACKNOWLEDGMENTS}

We would like to thank the Ministry of Research, Technology and Higher Education (Kemenristekdikti) Indonesia for funding this research. The Research and Community Service Institution (LPPKM) and the Faculty of Teacher Training and Education of the Tanjungpura University for providing the place and time to conduct this research. We would also like to thank the schools in the Kubu Raya District and North Kayong Districts for their collaboration that made this research possible.

\section{REFERENCES}

Ahmadi, \& Dkk. (2008). Psikologi Sosial. Jakarta: Rineka Cipta.

Long, H. B. (1991). College students' selfdirected learning readiness and educational achievement, In H. B. Long \& Associates, eds. Self-directed learning: Consensus and conflict. Oklahoma: Oklahoma Research Center for Continuing Professional and Higher Education of The University of Oklahoma.

Cazan, A.-M., \& Schiopca, B.-A. (2014). Selfdirected Learning, Personality Traits and Academic Achievement. Procedia Social and Behavioral Sciences, 127, 640-644.

https://doi.org/10.1016/j.sbspro.2014.03.3 27

Deporter, B., \& Mike, H. (2008). Quantum Learning. Membiasakan Belajar Nyaman 
dan Menyenangkan. Bandung: Kaifa.

Hurlock, Elizabeth, B. (2000). Psikologi Perkembangan. Jakarta: Erlangga.

Kostelnik, Et., \& Al. (1999). Developmentally Appropriate Curriculum. Ohio: Merrill an imprint of Prentice Hall.

Levett-jones, T. L. (2005). Self-directed learning: Implications and limitations for undergraduate nursing education, 363368.

https://doi.org/10.1016/j.nedt.2005.03.003

Linn, Robert, L., Gronlubd, \& Norman, E. (1995). Measurement and Assesment in Teaching, Seventh Edition. Englewood Cliffs-New Jersey: Prentice-Hall Inc.

Loyens, S. M. M., Magda, J., \& Rikers, R. M. J. P. (2008). Self-directed learning in problem-based learning and its relationships with self-regulated learning. Educational Psychology Review, 20(4), 411-427. https://doi.org/10.1007/s10648008-9082-7

Miarso, Y. (2005). Menyamai Benih Teknologi Pendidikan. Jakarta: Pustekkom Kencana.

Nugraha, N., Mustikari, I. D., \& Zuhri, A. A. (2018). Pengaruh Sumber Belajar Siswa Terhadap Prestasi Belajar Pkn Siswa Kelas Vii Di Mtsn Ngawi Semester Genap Tahun Pelajaran 2014/2015. Citizenship Jurnal Pancasila dan Kewarganegaraan, $3(2)$,

https://doi.org/10.25273/citizenship.v3i2.1 252

Prayitno, \& Erman, A. (2004). Dasar-Dasar Bimbingan dan Konseling. Jakarta: PT. Rineka Cipta.

Ramli, N., Muljono, P., \& Afendi, F. M. (2018). External Factors, Internal Factors and Self-Directed Learning Readiness. Journal of Education and e-Learning Research, 5(1), 37-42. https://doi.org/10.20448/journal.509.2018. 51.37 .42

Saeid, N., \& Eslaminejad, T. (2016). Relationship between Student's SelfDirected-Learning Readiness and Academic Self-Efficacy and Achievement Motivation in Students. International Education Studies, 10(1), 225. https://doi.org/10.5539/ies.v10n1p225
Sanjaya, W. (2006). Strategi Pembelajaran Berorientasi Standart Proses Pendidikan. Jakarta: Kencana Prenada Media.

Sudijono, A. (2011). Evaluasi Pendidikan. Jakarta: PT. Raja Grafindo Persada.

Suhendri, H. (2012). Pengaruh Kecerdasan Matematis-Logis, Rasa Percaya Diri, Dan Kemandirian Belajar Terhadap. Kontribusi Pendidikan Matematika dalam Membangun Karakter Guru dan Siswa, (November), 978-979.

Sunarsih, T. (2009). Hubungan antara Motivasi Belajar, Kemandirian Belajar dan Bimbingan Akademik terhadap Prestasi Belajar Mahasiswa di Stikes A. Yani Yogyakarta. Surakarta: Universitas Sebelas Maret.

Sutama, A. (2001). Faktor-faktor Motivasi. Gapura Angkasa. Makasar: PPS-UH.

Tahar, I., \& Enceng. (2006). Hubungan Kemandirian Belajar Dan Hasil Belajar Pada Pendidikan Jarak Jauh. Jurnal Pendidikan Terbuka dan Jarak Jauh, 7(2), 91-201.

Winkel. (2004). Psikologi Pendidikan Dan Evaluasi Belajar. Jakarta: PT. Gramedia. 